\title{
RELATIONSHIP BETWEEN CHROMOSOMAL CHANGES AND ALTERATIONS IN THE BEHAVIOUR OF A STRAIN OF HUMAN SYNOVIAL CELLS DURING ITS LIFE HISTORY IN VITRO
}

BY

\author{
B. J. CLARRIS AND J. R. E. FRASER \\ From The University of Melbourne Department of Medicine, Royal Melbourne Hospital, Victoria, 3050, Australia.
}

The eventual occurrence of gross aberrations in the number and pattern of chromosomes is one $o$ the main objections to the use of cell cultures in the study of physiology and disease. Such aberrations are essential features of the permanent cell lines such as HeLa, and accompany the phenomenon of "transformation", in which radical changes occur in cell structure, growth, and secretory functions. Transformation to "established" cell lines is commonly observed in cells from healthy rat and mouse tissues growing in vitro (Levan and Biesele, 1958; Rothfels and Parker, 1959). Several examples have been recorded of similar transformations in cells propagated from human neoplasms (Gey, Coffman, and Kubicek, 1952; Fjelde, 1955; Berman, Stulberg, and Ruddle, 1957). In contrast, transformation rarely occurs in cells from "normal" human tissues and these can often be grown for considerable periods in continuous serial cultivation without serious deviations from the euploid state (Puck, Cieciura, and Robinson, 1958; Hayflick and Moorhead, 1961; Ferguson and Wansbrough, 1962). However, Saksela and Moorhead (1963) found that minor aneuploid changes occurred late in the life of the human strains WI26 and WI38. These chromosomal alterations could be clearly correlated with changes in the morphology and rates of growth of the cells.

Hsu, Pomerat, and Moorhead (1957) first reported chromosomal studies on normal human synovial cells in culture. They found early aneuploid changes in a "strain" of cells propagated from synovial explants. Castor (1960) briefly described similar chromosomal alterations in explanted human synovial cells. Ferguson found normal chromosome counts and karyotypes in three synovial strains studied after 58,71, and 106 days respectively (Fraser and McCall, 1965). The inference that synovial cells might be intrinsically unstable in vitro has not received further investigation. The present paper reports a study designed to contribute more detailed information on chromosomal and behavioural changes in human synovial cells in vitro.

\section{Material and Method}

\section{Origin of the Synovial Cell Strain}

The synovial cells used in this study were obtained from an intact human knee joint by a method developed in this laboratory (Fraser and Catt, 1961) and described in detail elsewhere (Fraser and McCall, 1965). Briefly, the synovial fluid was aspirated from the knee of an 86-year-old female patient after amputation for peripheral vascular occlusion and distal gangrene. The synovial cavity was rinsed with pre-warmed physiological saline ( 0.9 per cent.) and the synovial intimal cells dispersed by incubation for approximately 20 minutes with trypsin solution $(0.25$ per cent. in phosphatebuffered saline). The cell suspension was withdrawn and the trypsin decanted after centrifugation. The cells were grown in "Pyrex" milk dilution bottles (capacity $160 \mathrm{ml}$.) in culture medium consisting of medium 199 (Morgan, Morton, and Parker, 1950) supplemented with 10 per cent. $(\mathrm{v} / \mathrm{v})$ of heat-inactivated $\left(56^{\circ} \mathrm{C} . \times 30\right.$ minutes $)$ human serum and 10 per cent. foetal calf serum (Commonwealth Serum Laboratories, Melbourne). The strain was designated 66-2.

\section{Preparation of Cultures}

Suitable cultures were rinsed once with calcium- and magnesium-free Hanks' basic salt solution (CMF) and incubated with 0.25 per cent. trypsin solution for 15 to 20 minutes. The cells were agitated gently to achieve complete dispersion and a sample was counted by a Model A Coulter electronic cell counter. A volume of cell suspension was selected to provide a final cell density of approximately $5 \times 10^{4}$ cells per $\mathrm{ml}$. These cells were centrifuged for 5 minutes at about $100 \times \mathrm{g}$ and dispensed into covered "Pyrex" Petri dishes $(60 \times 15$ $\mathrm{mm}$.) containing glass coverslips. $5 \mathrm{ml}$. cell suspension were added to each dish. The cells were incubated for 48 hours at $37^{\circ} \mathrm{C}$. in air with sufficient carbon dioxide to maintain physiological $\mathrm{pH}$ (assessed by the phenol red indicator in synthetic medium 199). 


\section{Preparation of Metaphase Plates}

Colchicine ("Aqua-colchin"; Parke, Davis \& Co. Ltd., Sydney) was added to each culture to a final concentration of 0.5 to $1.0 \mu \mathrm{g} . / \mathrm{ml}$. The cultures were then incubated at $37^{\circ} \mathrm{C}$. for a further 2 hours. Glass-distilled water (pre-warmed to $37^{\circ} \mathrm{C}$.) was added slowly over a period of 10 minutes until the medium was diluted by 1.4. The coverslips were removed, drained, and fixed for 10 minutes in freshly-prepared acetic ethanol (glacial acetic acid: ethanol=1:3 v/v). The coverslips were rinsed in 45 per cent. acetic acid and dried for at least 3 hours at room temperature $\left(17^{\circ}\right.$ to $20^{\circ} \mathrm{C}$. $)$ and were stained with acetic orcein stain ( 2 per cent. solution of Gurr's synthetic orcein, prepared in hot 45 per cent. acetic acid and filtered immediately before use). The stained preparations were dehydrated in ethanol and xylol and finally mounted permanently in $\mathrm{DePeX}$ or polystyrene. Some fixed cultures were also stained with Leishman's stain which was found to produce excellent chromosome preparations.

All examinations were made under high-power oil immersion (magnification $700 \mathrm{X}$ ) on an Olympus microscope, using bright field optics and a green filter. Coverslips were scanned systematically and all mitoses which showed no evidence of scatter of chromosomes were counted. Each mitosis was centred in an eye-piece grid and the chromosomes were copied carefully onto graph paper. In later culture passages where cells frequently contained large numbers of chromosomes impossible to count accurately, estimates were made of the number of autosomes. An attempt was made to examine fifty cells in each culture passage examined. For various reasons this was possible for only four of the subcultures. Insufficient mitotic plates were available in the first preparation because of the limited number of cells available. In the final four culture passages mitoses were difficult to find because of the poor rate of cell division.

\section{Examination of Karyotypes}

All abnormal cells and a selected number of "normal" diploids were photographed using Ilford Pan F film. Enlarged prints were prepared and individual chromo- somes cut and arranged according to a modification of the system of classification suggested by Patau (1961; 1965).

\section{Results and Observations \\ Chromosomal Changes}

Assessment of mitoses was made in culture passages $2,3,6,7,9,11,15,18,19$, and 21 . A total of 336 plates was counted. The detailed distribution of chromosome numbers in the synovial cells is shown in Table I. The distribution was bimodal in the early subcultures, with centres at 46 and 91 to 92 chromosomes. Only minor fluctuations were seen in the proportion of diploid cells in the first fifteen culture passages. During this period, the largest deviation from constancy occurred in the sixth passage when it was possible to count only forty cells in the material available. This larger deviation may therefore reflect bias due to the limited sample.

The progressive alteration in proportions of dividing cells with diploid, tetraploid, and polyploid chromosome numbers is illustrated in Fig. 1 (opposite).

Beyond the fifteenth passage a marked instability occurred; this was first manifest as a spreading of the distribution of chromosome counts about the normal modal value, and finally as a shift of the modal value into the polyploid range. In this period dividing cells became increasingly difficult to find. In the final passage, the few mitotic cells contained huge numbers of chromosomes which were impossible to count.

Examination of karyotypes of all hyperdiploid and hypodiploid mitoses showed no consistent trends in chromosome deletions or additions. Deletions can easily occur by leaching of chromosomes through disrupted plasma membranes during processing. Similarly, cells may easily gain one or

TABLE I

DISTRIBUTION OF CHROMOSOME NUMBERS DURING THE GROWTH PERIOD OF SYNOVIAL CELL STRAIN 66-2

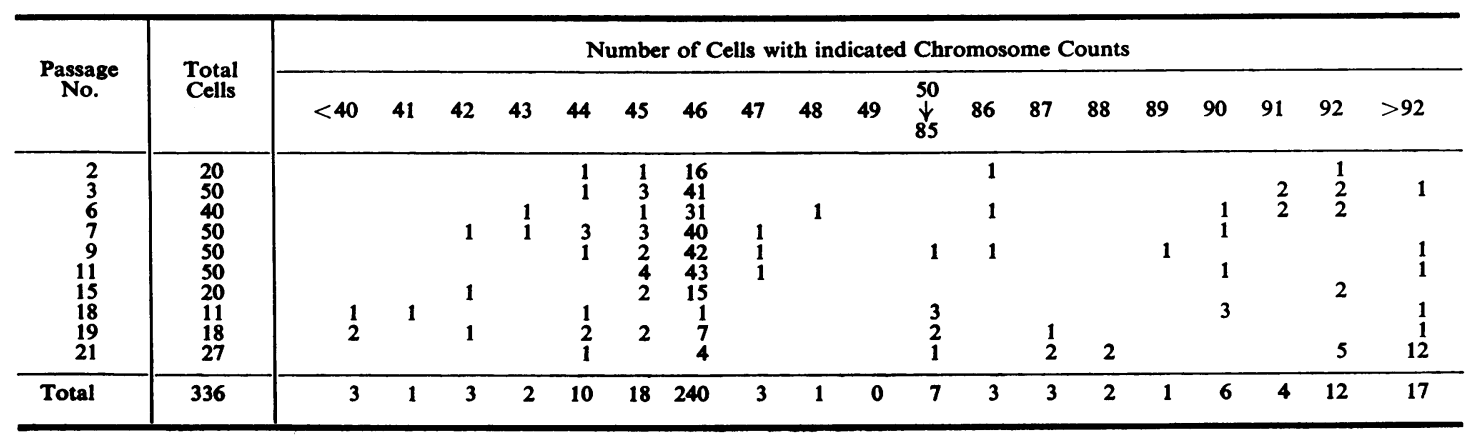




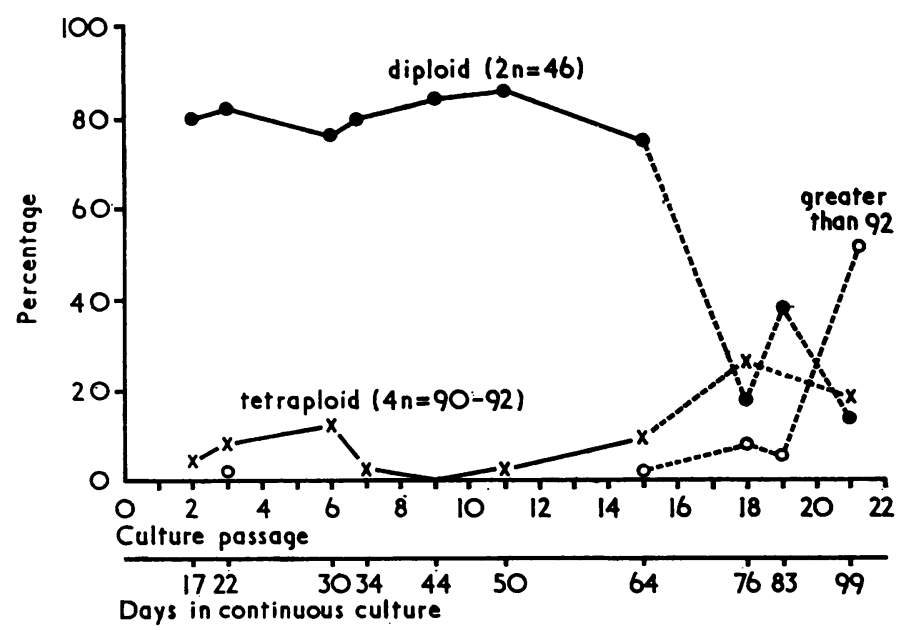

Fig. 1.- Changes in chromosome numbers in human synovial cell strain $\mathbf{6 6 - 2}$ in continuous culture. Hypodiploid and hyperdiploid cells are not plotted. Broken lines indicate stage of degeneration of strain.

more chromosomes from adjacent, scattered mitoses. A compromise was adopted in which cells with 44 to 48 chromosomes were regarded as "diploid". Cells with chromosome numbers beyond these limits were considered to be aneuploid. From passage 2 to passage 15 the proportion of aneuploid cells fluctuated from 4 to 14 per cent. Thereafter it ranged from 45 to 82 per cent. of the total dividing cells (Table II).

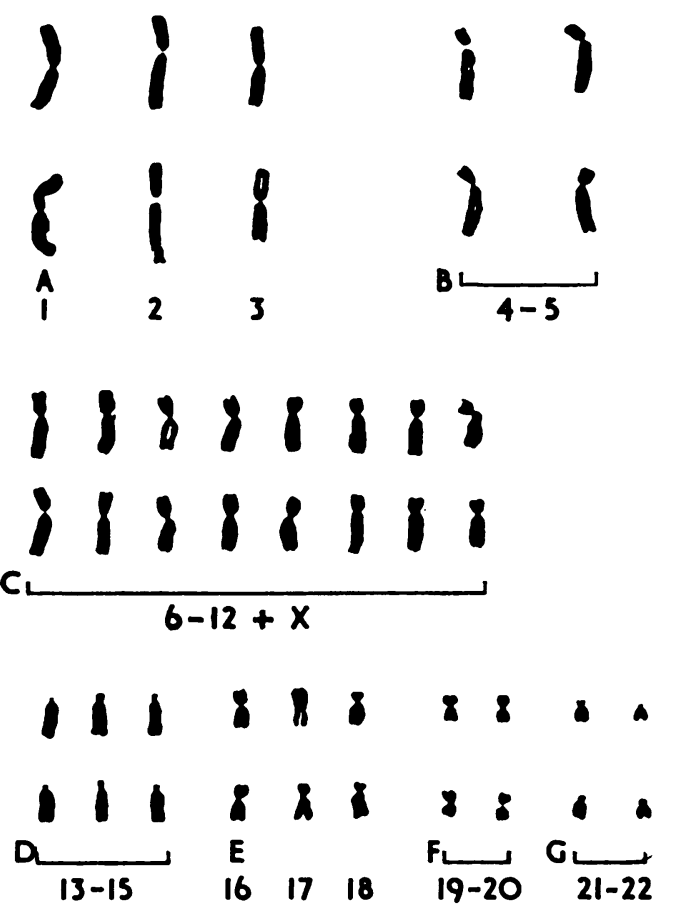

Apart from minor deviations from the diploid mode, the early culture passages were characterized by a small proportion of tetraploid and hypotetraploid cells (90 to 92 chromosomes). The percentage of these cells rose sharply after subculture 15 and then declined in favour of polyploids. Throughout the early culture passages the karyotypes of diploid cells were consistently normal with respect to specifications listed in the Denver Report of 1960. A karyogram prepared from a typical diploid mitosis is shown in Fig. 2. Chromosomal defects such as dicentrics, broken chromosomes, and

Fig. 2.-Karyogram prepared from a normal diploid mitosis.

chromosomal bridges were not seen in this study. Occasional examples of endomitotic reduplication (Levan and Hauschka, 1953) were observed throughout the examination (Fig. 3, overleaf).

Morphological Changes and Alterations in Rate of Multiplication associated with Chromosomal Abnormalities

Alterations in the behaviour of the cell strain under examination closely paralleled the onset of 


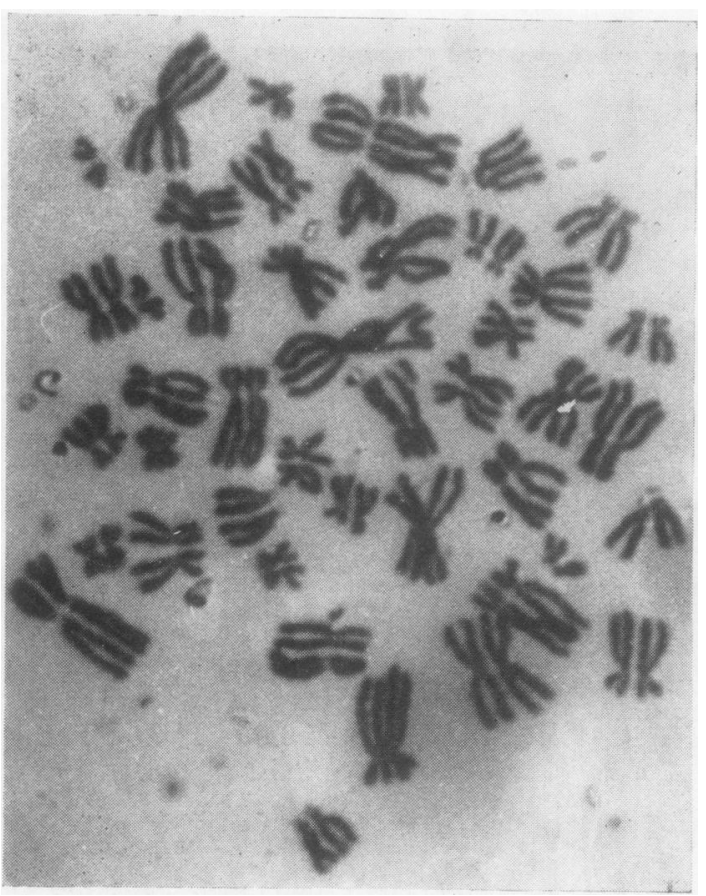

Fig. 3.-Example of endomitotic reduplication from passage 9 . Acetic orcein stain. Bright field. $\times 1,400$

major chromosomal changes. Until passage 15 , the cells multiplied rapidly and formed cell sheets in which individual cells exhibited a degree of apparent contact inhibition (Fig. 4a). Thereafter the rate of proliferation declined and the cell layers tended to become ragged with cells lying across one another seemingly without contact inhibition (Fig. $4 b$ ). Deterioration progressed until finally only isolated cells survived trypsinization (Figs $4 c$ and $4 d$ ). During the degenerative stage the cells showed a temporary increase in capacity to secrete hyaluronic acid. Large amounts of cell debris accumulated in the medium and much of this became attached to cells.

\section{Discussion}

Several studies have been carried out on chromosomal variations in aneuploid cell-lines (Saksela, 1962; Spurná and Hill, 1967). However, there have been few investigations of the type described in this paper on recently isolated human cell "strains" and little information is available to compare the chromosomal changes seen in human synovial cells and those in other human strains. During the present investigation, only two limited accounts were found of chromosomal alterations in human synovial cells. Hsu and others (1957) examined changes in morphology of cells and chromosome numbers in the "Mayes" strain derived from explants of normal human synovium. These cells were cultivated in a complex medium containing chicken embryo extract and ascitic fluid. The authors could not find any mitotic plates during the first four culture passages which encompassed a period of more than 4 months. By this time considerable changes had occurred and only 31 of a total of 49 mitoses counted had the normal human complement of 46 chromosomes. Hence, it was not possible to ascertain at what stage the aberrations began to occur. In a later study, Castor (1960) found early aneuploid alterations in cell strains derived from healthy human synovium and from synovial membranes of patients with rheumatoid arthritis or with systemic lupus erythematosus. As with the earlier study, the cells examined by Castor (1960) were propagated from explants.

The behaviour of the strain used in the present investigation was similar to that of the human diploid strains WI26 and WI38 described by Saksela and Moorhead (1963). As in these studies, the changes in the rate of multiplication and in the appearance of the synovial cells were easily recognized and also appeared to correspond closely with the development of chromosomal instability. Miscellaneous observations on several other synovial strains, not documented in detail in the present paper, showed similar correlations between phenotypic and chromosomal deviations.

Strains WI26 and WI38, derived from normal foetal lung tissue, could be serially cultivated for more than fifty passages (Saksela and Moorhead, 1963), whereas synovial strain 66-2 failed completely after the 21st sub-cultivation. Although many synovial strains used in this laboratory have shown normal "diploid" growth patterns for periods up to 120 days in continuous culture, it is uncommon for these strains to persist for more than 140 days. Transformation has never occurred in any of our synovial strains and in this respect they behave in a similar fashion to other strains derived from nonmalignant human tissues.

The proportion of aneuploid cells seen in strain 66-2 is slightly higher than that recorded in a number of human euploid strains (Puck and others, 1958; Makino, Kikuchi, Sasaki, Sasaki, and Yoshida, 1962; Saksela and Moorhead, 1963). Castor (1960) found even more pronounced trends towards aneuploidy in synovial cultures derived from healthy subjects and from patients with arthritic disease. It is conceivable that cells from synovial 


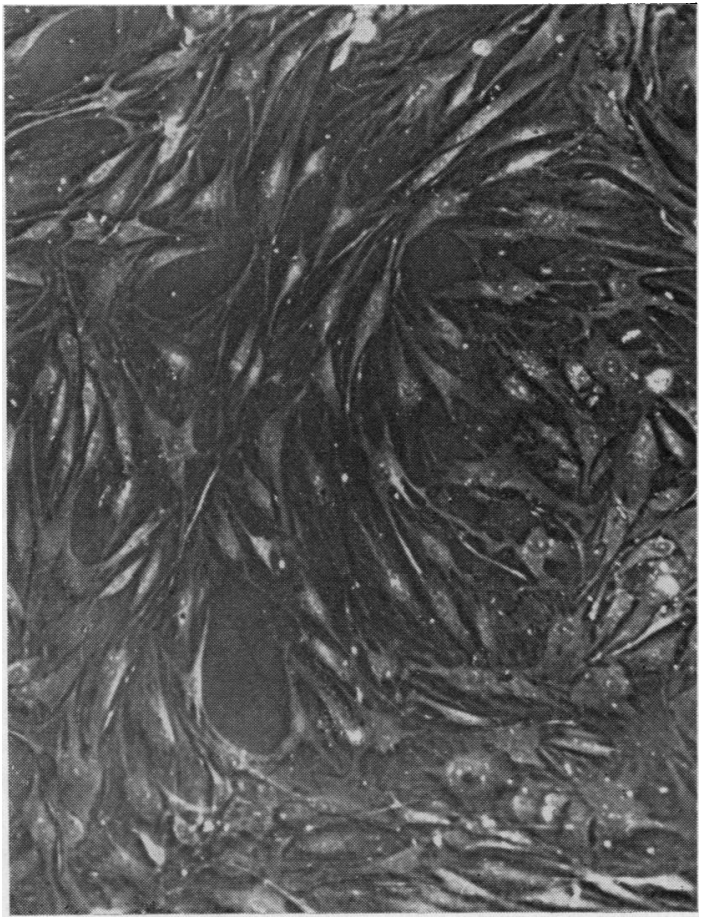

Fig. 4a.-Appearance of synovial cells between passages 6 and 7 , immediately before subcultivation. Note parallel arrangement of cells and apparent "contact inhibition" between cells. Negativehigh phase. $\times 65$.

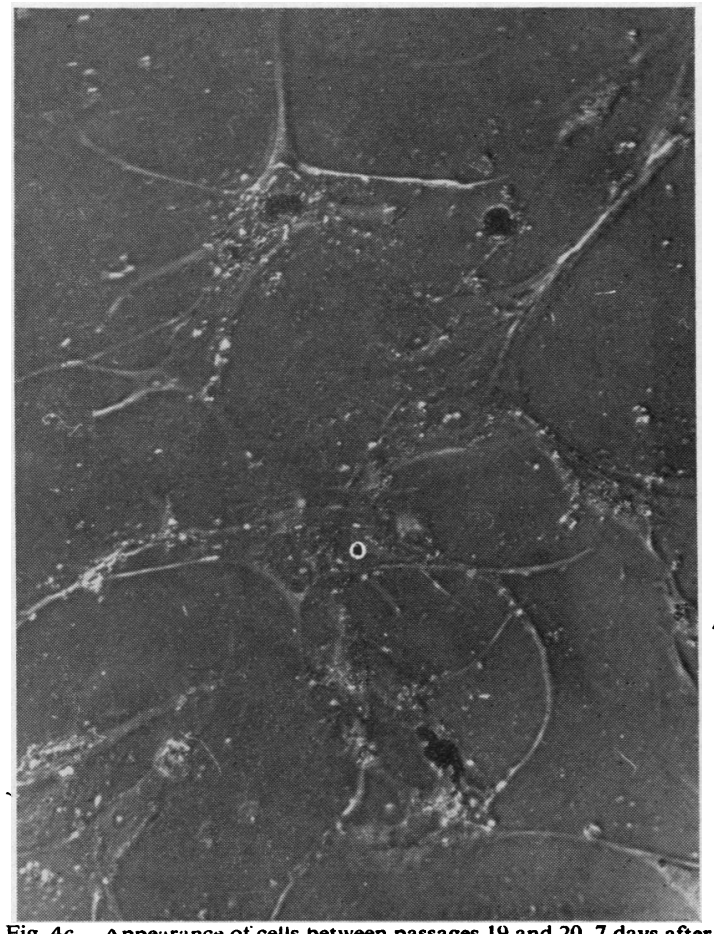

Fig. 4c.-Appearance of cells between passages 19 and 20,7 days after subcultivation. Negative-high phase. $\times 65$.

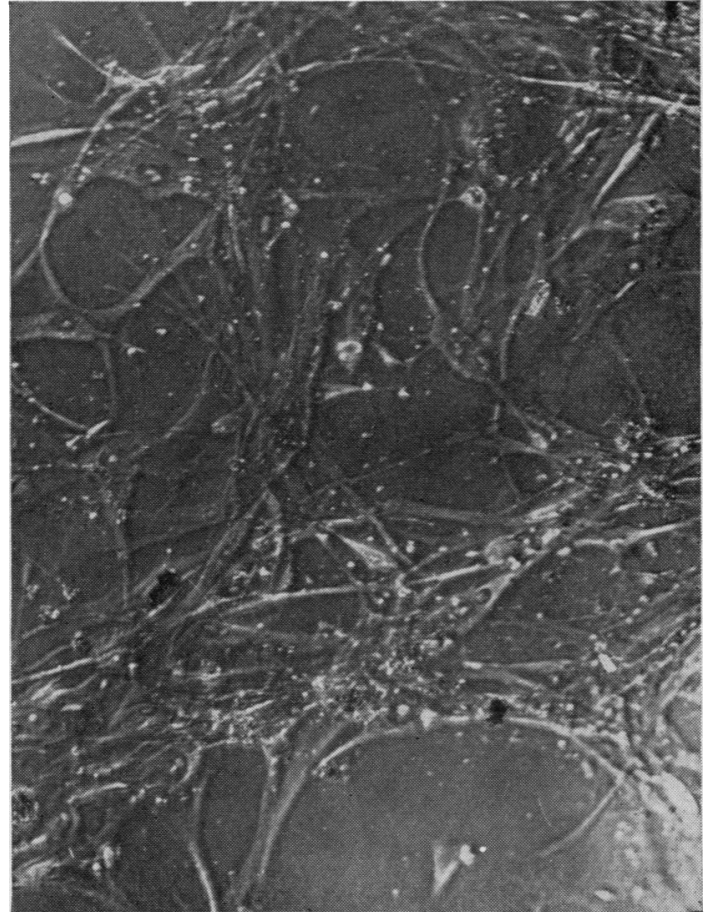

Fig. 4b.-Appearance of cells between passages 17 and 18, 5 days after subcultivation. The cells lie randomly and show no contact inhibition. Negative-high phase. $\times 65$.

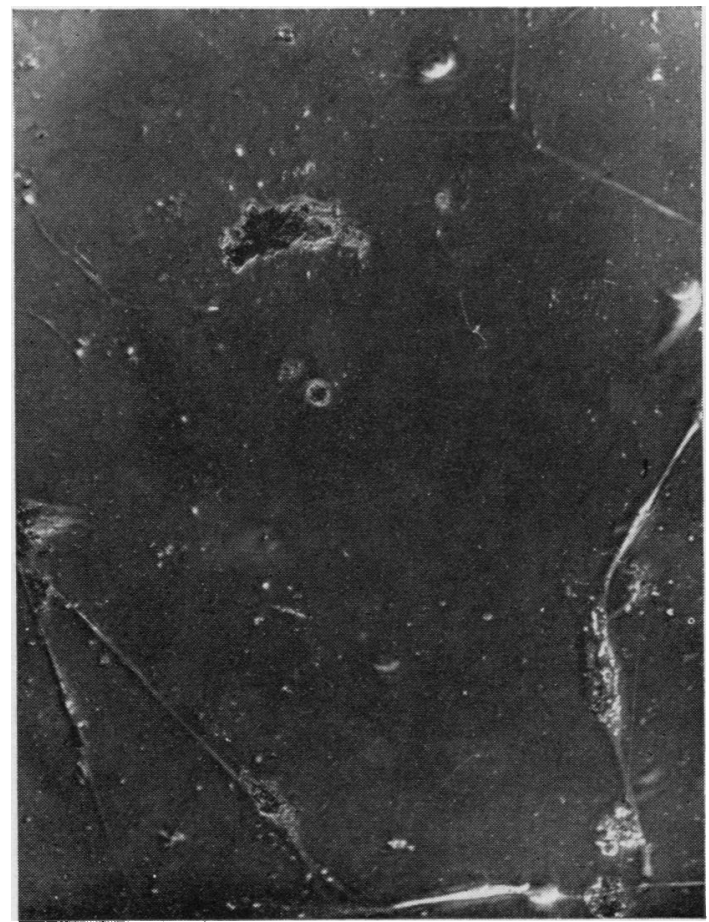

Fig. 4d.-Appearance of cells 5 days after passage 21. Negative-high phase. $\times 65$ 
tissue are inherently more unstable than those from other tissues although there is no obvious reason why this should be so. A factor common to the present work and that of Castor (1960) is the use of human serum in the medium employed to cultivate synovial cultures. Foetal calf serum appears to maintain chromosomal stability in cultured cells (Puck and others, 1958; Hayflick and Moorhead, 1961; Ferguson and Wansbrough, 1962). In the growth medium used to propagate strain 66-2, foetal calf serum constituted only one half of the serum component, the rest being heat-inactivated human serum. No documented evidence has been found describing adverse effects of human serum on the chromosomal stability of diploid strains. However, fresh and heat-inactivated human sera produce variable effects on HeLa cells (Saksela, 1962; Saksela and Saxén, 1962). Thus, fresh human serum reduced the modal chromosomal value of the HeLa stem-line relative to that of cells grown in heated serum. Individual batches of fresh serum showed some variation in this property. It is therefore possible that heat-inactivated human serum could cause minor chromosomal changes in diploid strains. Even so, in the growth medium employed in this study and in routine serial cultivation of synovial cells in this laboratory, strain 66-2 showed a long period of chromosomal stability. The correlation between alteration in growth rate and culture morphology and the development of gross chromosomal abnormalities was close enough to suggest that synovial cells selected before the onset of phenotypic aberrations could be assumed with confidence to be substantially euploid.

\section{Summary}

Cells derived from a "normal" human synovial membrane remained substantially diploid for fifteen serial passages encompassing a period of more than 60 days in continuous culture in medium containing synthetic medium 199 supplemented with heatinactivated human serum and foetal calf serum. During the diploid phase, cells multiplied at a uniform rate and formed regular monolayers. After the fifteenth subculture the synovial cells began to develop increasing numbers of chromosomal abnormalities including tetraploid and polyploid mitoses. Just before the final deterioration of the strain, a high proportion of the dividing cells became grossly polyploid.

Concurrently with the chromosomal changes, the synovial cells began to develop obvious morphological abnormalities and a marked reduction occurred in multiplication rate. Cells eventually failed to divide and could not be maintained beyond the one hundredth day in culture. The close agreement between chromosomal alterations and behavioural changes in the synovial cell strain suggests that the phenotypic state of the strain is indicative of its chromosomal stability.

This work was made possible by grants from the Arthritis and Rheumatism Council for Research in Great Britain and the Commonwealth, the National Health and Medical Research Council of Australia, and the Australian Rheumatism Council. We are grateful to Mrs. C. Flanders for technical assistance.

\section{REFERENCES}

Berman, L., Stulberg, C. S., and Ruddle, F. H. (1957). Cancer Res., 17, 668 (Human cell culture. Morphology of the Detroit strains).

Böök, J. A., and 16 others (Denver Report) (1960). Lancet, 1, 1063 (A proposed standard system of nomenclature of human mitotic chromosomes).

Castor, C. W. (1960). Arthr. and Rheum., 3, 436 (Chromosomal numbers in cells cultured from human synovial tissue).

Ferguson, J., and Wansbrough, A. (1962). Cancer Res., 22, 556 (Isolation and long-term culture of diploid mammalian cell lines).

Fjelde, A. (1955). Cancer (Philad.), 8, 845 (Human tumor cells in tissue culture).

Fraser, J. R. E., and Catt, K. J. (1961). Lancet, 2, 1437 (Human synovial-cell culture: Use of a new method in a study of rheumatoid arthritis).

- and McCall, J. F. (1965). Ann. rheum. Dis., 24, 351 (Culture of synovial cells in vitro).

Gey, G. O., Coffman, W. D., and Kubicek, M. T. (1952). Cancer Res., 12, 264 (Tissue culture studies of the proliferative capacity of cervical carcinoma and normal epithelium).

Hayflick, L., and Moorhead, P. S. (1961). Exp. Cell Res., 25, 585 (The serial cultivation of human diploid cell strains).

Hsu, T. C., Pomerat, C. M., and Moorhead, P. S. (1957). J. nat. Cancer Inst., 19, 867 (Mamalian chromosomes in vitro. VIII. Heteroploid transformation in the human cell strain Mayes).

Levan, A., and Biesele, J. J. (1958). Ann. N. Y. Acad. Sci., 71, 1022 (Role of chromosomes in cancerogenesis, as studied in serial tissue culture of mammalian cells). 
— and Hauschka, T. A. (1953). J. nat. Cancer Inst., 14, 1 (Endomitotic reduplication mechanisms in ascites tumors of the mouse).

Makino, S., Kikuchi, Y., Sasaki, M. S., Sasaki, M., and Yoshida, M. (1962). Chromosoma (Berl.), 13, 148 (A further survey of the chromosomes in the Japanese).

Morgan, J. F., Morton, H. J., and Parker, R. C. (1950). Proc. Soc. exp. Biol. (N.Y.), 73, 1 (Nutrition of animal cells in tissue culture. I. Initial studies on a synthetic medium).

Patau, K. (1961). Lancet, 1, 933 (Chromosome identification and the Denver Report).

(1965). "Identification of Chromosomes" in "Human Chromosome Methodology", ed. J. J. Yunis, pp. 155-186. Academic Press, London, New York.

Puck, T. T., Cieciura, S. J., and Robinson, A. (1958). J. exp. Med., 108, 945 (Genetics of somatic mammalian cells. III. Long-term cultivation of euploid cells from human and animal subjects).

Rothfels, K. H., and Parker, R. C. (1959). J. exp. Zool., 142, 507 (The karyotypes of cell lines recently established from normal mouse tissues).

Saksela, E. (1962). Acta. path. microbiol. scand., Suppl. 153 (The effect of different human sera on the karyologic picture of HeLa cells).

- and Moorhead, P. S. (1963). Proc. nat. Acad. Sci. (Wash.), 50, 390 (Aneuploidy in the degenerative phase of serial cultivation of human cell strains).

— and Saxén, E. (1962). Acta path. microbiol. scand., 54, 253 (Chromosomal heterogeneity of cell lines in vitro. 3. The effect of individual fresh human sera on the mitosis of HeLa cells).

Spurna, V., and Hill, M. (1967). Neoplasma (Bratisl.), 14, 11 (Chromosomal composition of HeLa and $L$ cells in tissue cultures).

Altérations des chromosomes et comportement d'une souche de cellules synoviales humaines

\section{RÉSUMÉ}

Des cellules dérivées d'une membrane synoviale humaine "normale" maintenaient la forme essentiellement diploïde au cours de quinze passages en série comprenant une période de plus de 60 jours dans un milieu de culture continue, contenant le milieu synthétique 199 auquel on ajoutait du sérum humain inactivé par la chaleur et du sérum foetal bovin. Pendant la phase diploïde la vitesse de la multiplication était uniforme, par couches monocellulaires. Après le quinzième passage les cellules synoviales commencèrent à développer un nombre croissant d'anomalies chromosomiques comprenant des mitoses tetraploïdes et polyploïdes. Peu avant la détérioration finale de la souche, une forte proportion des cellules en division devint très polyploïde.

Parallèlement aux altérations des chromosomes, les cellules synoviales développaient des anomalies morphologiques marquées et la multiplication se ralentissait considérablement. Finalement la division cessa et on ne put pas la maintenir au delà du centième jour de la culture. Cette correspondence étroite entre les altérations des chromosomes et le comportement de la souche des cellules synoviales suggère que l'état phénotype de la souche est un indicateur de la stabilité des chromosomes.
Alteraciones de los cromosomas y el comportamiento de una cepa de células sinoviales humanas

\section{SUMARIO}

Células derivadas de una membrana sinovial humana "normal" mantuvieron la forma esencialmente diploide en el curso de quince pasajes en serie, incluyendo un período de más de 60 días de cultivo continuo en el medio sintético 199 con adición de suero humano inactivado por el calor y de suero fetal bovino. Durante la fase diploide la velocidad de la multiplicación fué uniforme en capas monocelulares. Después de quince pasajes las células sinoviales empezaron a desarrollar un número creciente de anomalías cromosómicas con mitosis tetraploides y poliploides. Poco antes de la deterioración final de la cepa, una fuerte proporción de las células en el curso de división so volvió muy poliploide.

Concurrentemente con las alteraciones cromosómicas, las células sinoviales desarrollaron anomalías morfológicas marcadas y la velocidad de su multiplicación se redujo considerablemente. Finalmente la división se acabó y no se pudo mantenerla más alla de cien días de cultivo. Este acuerdo intimo entre las alteraciones cromosómicas y el comportamiento de la cepa de células sinoviales sugiere que el estado fenotípico de la cepa es indicativo de la estabilidad cromosómica. 